\title{
比較的まれな手指末節部への肺がん転移の一症例
}

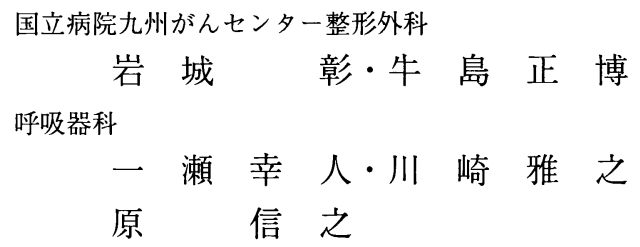

\section{A Case of Metastatic Lung Cancer to the Distal Phalanx}

by

\author{
Akira Iwaki and Masahiro Ushijima \\ Department of Orthopedic Surgery, \\ National Kyushu Cancer Center \\ Masayuki Kawasaki, Nobuyuki Hara and Yukito Ichinose \\ Department of Chest Surgery, \\ National Kyushu Cancer Center
}

Metastatic carcinoma in the hand is very rare. We now report a case of the metastatic lesion to the distal part of the finger from lung cancer, diagnosed by biopsy as squamous cell carcinoma. A 64-year-old man presented with a swelling and pain of the distal phalanx of the left ring finger. The swelling with blister had increased in size, resulting in ulcer formation. X-rays of the involved finger showed an area of lytic destruction of the distal phalanx. Amputation at the proximal phalanx of the left ring finger was performed, and pain was completely vanished. Histological examination showed well differentiated squamous cell carcinoma, similar to the primary lung lesion. Metastases to the hand from other malignant tumors are very rare, the incidence of hand involvement being $0.2 \%$ of all osseous metastases. Clinical manifestations resemble inflammatory diseases, such as whitlow, felon, osteomyelitis or gout. A high degree of suspicion, radiographs and biopsy help to clinch a correct diagnosis. A diagnosis of metastasis to the hand connotes a poor prognosis, proclaiming welladvanced and disseminated disease, which indicates that almost all patients are dead within six months.

はじめに

癌の四肢末梢への転移は稀なものとされてい る ${ }^{13}{ }^{37}$ 7) 8). 今回我々は肺癌の左環指末節部への転移 例を経験したので報告する.

\section{症例}

患者 : 64 歳, 男性

主訴 : 左環指末節部の腫脹・疼痛

既往歴 : 平成元年 11 月始め気管支鏡下の生検にて
扁平上皮癌と診断され，化学療法 (CDDP + VDS)， 放射線療法（前縦隔 $50 \mathrm{~Gy}$, 左鎖骨上窩 $50 \mathrm{~Gy}$ ）が施 行されている.

現病歴: 平成 2 年 6 月初め頃より左環指末節部に水 泡形成を伴う腫脹, 疼痛が出現し, 症状の軽快をみな いため当院呼吸器科にて切開を受けたが, その後難治 性の漬瘍を形成したため, 同年 6 月 29 日当科外来受 診となる。

家族歴 : 特記すべきことなし

初診時所見 : 左環指末節部掌側に直径 $1.5 \mathrm{~cm}$ のカ 


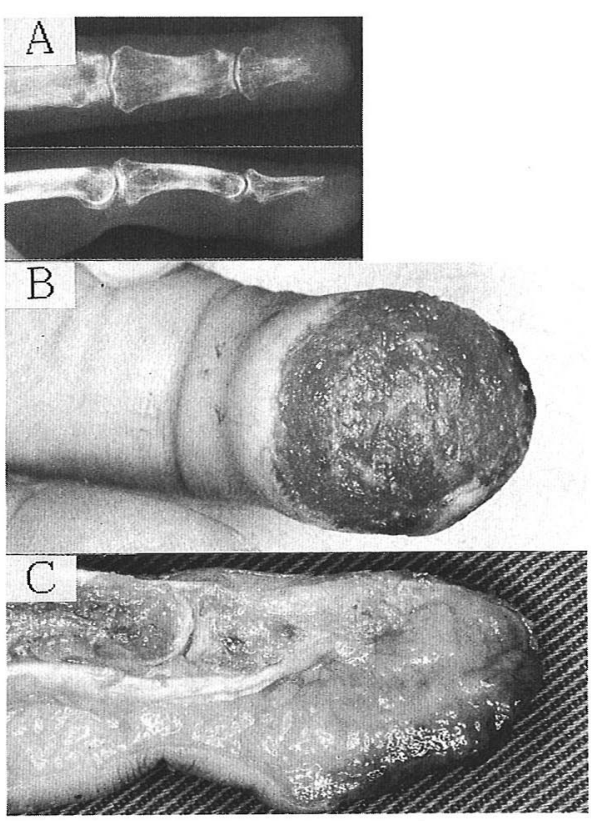

図1 A : 末節部の一部の骨融解像を認める

B : カリフラワー状の潰瘍形成を認め, 易出血 性で浸出液を伴っている

$\mathrm{C}:$ 腫瘍は灰白色で主に軟部組織に存在し, 一 部末節骨の破壊を認める

表1 原発性肺がんの骨転移例

\begin{tabular}{lcc}
\hline \hline 部位 & 患者数 & $(\%)$ \\
\hline 肋骨 & 91 & $(49.2 \%)$ \\
胸椎 & 84 & $(45.4 \%)$ \\
腰椎 & 76 & $(41.1 \%)$ \\
骨盤 & 72 & $(38.9 \%)$ \\
大腿骨 & 28 & $(15.1 \%)$ \\
頭蓋骨 & 25 & $(13.5 \%)$ \\
頸椎 & 19 & $(10.3 \%)$ \\
肩甲骨 & 17 & $(9.2 \%)$ \\
上腕骨 & 11 & $(5.9 \%)$ \\
鎖骨 & 7 & $(3.8 \%)$ \\
胸骨 & 7 & $(3.8 \%)$ \\
脛骨 & 7 & $(3.8 \%)$ \\
仙骨 & 2 & $(1.1 \%)$ \\
足根骨 & 1 & $(0.5 \%)$ \\
手指骨 & 0 & $(0 \%)$ \\
\hline
\end{tabular}

リフラワー状の潰瘍形成を認め，易出血性であり，疼 痛を訴えていた（図 1 -B).

臨床検査成績 : 特記すべきことなし

単純X線所見：左環指末節遠位部に軟部腫瘍の陰影 が見られ，末節骨の一部に骨融解像が認められた（図 $1-\mathrm{A})$.

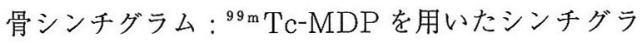
ムでは頭部への集積が強く，単純写真にても同部に骨 融解像が認められた。他に左第十肋骨にも集積が認め られた。左環指末節骨への集積は認められず，右手と 比較すると左手の方が集積が強く, 廃用性のものと思 われた（図 2 ).

治療および経過：生検にて診断確定後，左環指基節 骨部で切断術を施行した。腫瘍は死白色で，主に軟部 組織に存在し，一部末節骨の破壊を認めた（図 $1-C$ ). 病理組織学的検索では原発巣の組織像と類似した高分 化型の扁平上皮癌の像を呈していた，術後自発痛およ び運動痛は消失した。

\section{考察}

癌の骨転移のうち时より末梢, 特に手における転移 の発生は比較的稀である。1964 年, Clain ${ }^{2)}$ は転移性 骨腫痬症例 2001 例中 5 例 $(0.2 \%)$ に手指への転移が 認められたと報告しているままた全国骨腫瘍患者登録 一覧表でも，昭和 47 年から昭和 63 年までの 17 年間 の癌の骨転移例は 8682 例で, 指骨への転移はわずか に 19 例 $(0.2 \%)$ と非常に少ない. 原発部位は肺癌が 最も多く，表 1 は国立病院九州がんセンターにおける 過去十年間の原発性肺癌 1180 例の骨転移の状況を示 している5゙．185例に骨転移が認められ，その内訳は 表に示すごとくであり，手指骨への転移は今回の症例 が初めてである（表 1 ）。臨床所見は発赤, 腫脹, 圧 痛といった炎症所見を伴うことが多く，報告例のほと んどが発症時には骨髄炎や瘭疽，痛風などが疑われ， それらに対する治療を受けた症例の報告もあり ${ }^{13)}$, 臨床的にその鑑別は非常に困難である．悪性腫瘍の手 指への転移は他の部位への転移を伴わない単発例の報 告や，肺癌の初発症状であった症例の報告もあるが， 一般的には全身性転移の部分症状と考えられ，手指転 移発現後の予後は概して不良でほぼ全例が 6 力月以内 に死亡している ${ }^{4)}$. 


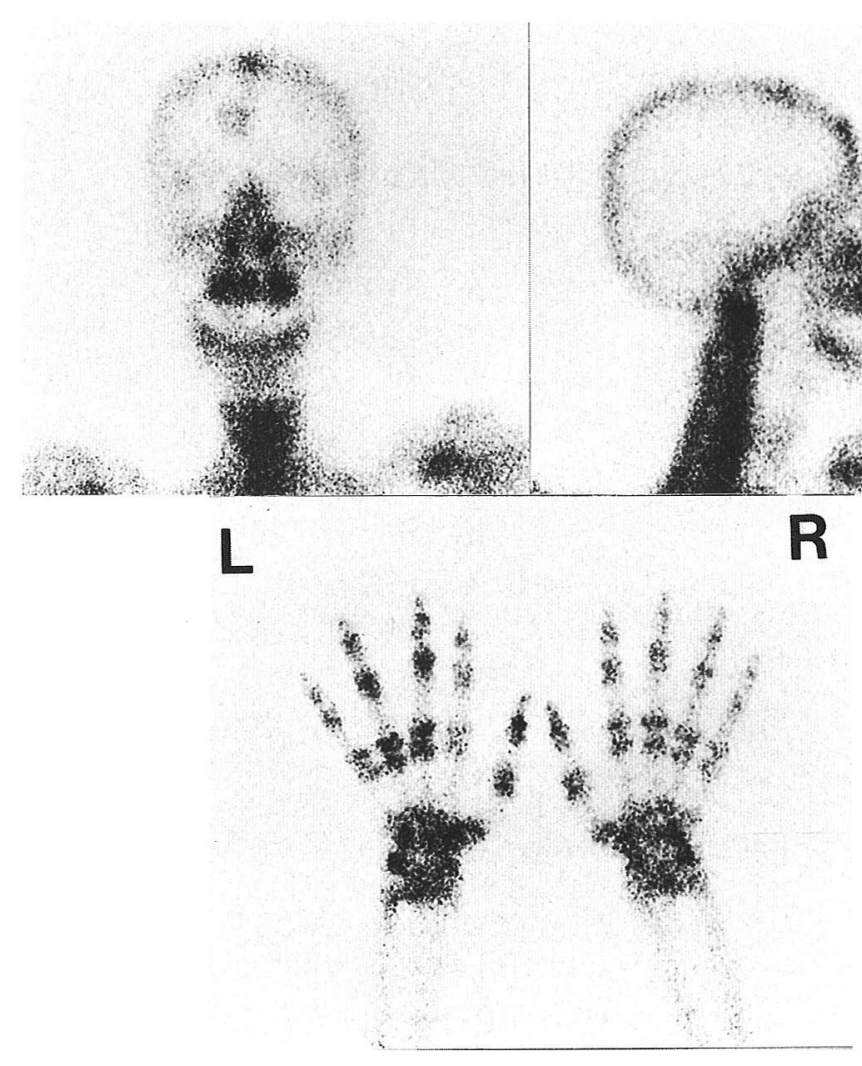

図 2 頭部への集積が強く，また右手に比べると左手 の方が全体的に集積が強い.

ま と め

(1)比較的稀な手指末節部への肺癌転移例を報告した. (2)肺癌の手指末節部への転移例は炎症性疾患に類似 した初発症状を伴って発症する事が多く注意を要する.

(3)手指末節部に転移をきたした例の多くは多発転移 を有しており，予後は不良である。

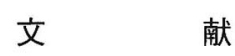

1) Bricout, P. B.: Acrometastases. J. Natl. Med. Assoc., $73: 325-329,1981$.
2) Clain, A.: Secondary malignant disease of bone Brit.J. Cancer, $19:$ 15-29, 1964.

3) Healey. J. H.: et al Acrometastases. J. Bone Joint Surg., 68-A : 743-746, 1986.

4）亀井治人ほか：手指への転移をきたした肺癌の 4 例. 骨転移・病態・診断・治療, $6: 50-55,1989$.

5）川崎雅之ほか：肺癌骨転移の検討. 肺癌, 30:359-364, 1990.

6）日整会骨腫瘍委員会 : 全国骨腫瘍患者登録一覧表. 国 立がんセンタ一, 1988.

7）斉藤 裕ほか：母指末節骨転移を認めた肺癌の 1 例. 臨床放射線, $28: 483-486,1983$.

8）土屋 敦ほか：指骨に転移した肺癌の 1 例. 整形外科, $36: 380-383,1985$. 